www.jmscr.igmpublication.org

Impact Factor 5.84

Index Copernicus Value: 71.58

ISSN (e)-2347-176x ISSN (p) 2455-0450

crossref DOI: _https://dx.doi.org/10.18535/jmscr/v5i11.82

Journal Of Medical Science And Clinical Research

IGM Publication

An Official Publication of IGM Publication

\title{
Comparison of Endometrial Changes in Uterine Leiomyoma and Adenomyosis of Uterus with Correlation of Serum Estradiol and Progesterone Levels
}

\author{
Authors \\ Debosmita Bhattacharyya ${ }^{1}$, Anadi Roy Chowdhury ${ }^{2}$ \\ ${ }^{1}$ Junior Resident, ${ }^{2}$ Associate Professor \\ Department of Pathology, R.G.Kar Medical College and Hospital \\ Corresponding Author \\ Debosmita Bhattacharyya \\ Department of Pathology, R.G.Kar Medical College and Hospital \\ 1, Khudiram Bose Road, Kolkata- 700004, West Bengal, India \\ Phone Number-9804263032, Email-debosmitacupcakes@gmail.com
}

\begin{abstract}
Background: Both leiomyoma and adenomyosis are commonly encountered gynecological pathologies. It is a well-established fact that hyperestrogenic state is associated with growth of leiomyoma but the exact etiology of adenomyosis is unknown. Adenomyosis is also thought to be an estrogen dependent disease. Similarly, it has also been found that progesterone receptors are increased in leiomyomas whereasa decreased responsiveness of the ectopic endometrium to progesterone has been found in adenomyosis. Thus these two hormones are intricately related to leiomyoma and adenomyosis.

Aims: The aim of this study is to note the changes in endometrium that can be found in the respective cases of uterine leiomyoma and adenomyosis of uterus.

Materials and Methods: The study was conducted over a period of 12 months included 73 cases of leiomyoma and 73 cases of adenomyosis. Serum estradiol and progesterone levels of all the patients were measured by chemiluminescence immunoassay.

Results: In leiomyoma, inactive basal endometrium was the most common finding 36/73 (49.31\%) and in adenomyosis simple hyperplasia of endometrium was found in majority 30/73 (41.09\%). However, both estradiol and progesterone levels in leiomyoma and adenomyosis were mostly within the normal range.

Conclusion: Though both leiomyoma and adenomyosis are associated with a hyper estrogenic state, leiomyoma had inactive basal endometrium while adenomyosis had hyperplasia. Adenomyosis was also found to be associated with other pathologies like endometrial carcinoma, complex hyperplasia. Hence, in adenomyosis other associated pathologies should be looked for.

Keywords: Inactive basal endometrium, endometrial hyperplasia, estradiol, progesterone.
\end{abstract}

\section{Introduction}

The endometrium is uniquely endowed throughout the female reproductive lifespan with complex regular cycle of periodic proliferations, differentiation, breakdown and regeneration. Before puberty the endometrial tissue is inactive, it is composed of tubular glands, a dense fibroblastic stroma and thin blood vessels. In normal menstrual cycles, the menstrual shedding 
is followed by endometrial proliferation under estrogenic stimulation. After ovulation, the secretion of progesterone inhibits the proliferative activity of the endometrium and induces a complex secretory activity within the endometrium. ${ }^{1}$ During climacteric, ovarian activity declines. Initially, ovulation fails, no corpus luteum forms, and no progesterone is secreted by the ovary. ${ }^{2,3}$ Hyperplasias of the endometrium can develop in woman at any age with unopposed estrogen. Hyperplasia with cytologic atypia represents the greatest risk for progression to endometrial carcinoma and the presence of concomitant carcinoma in women with endometrialhyperplasia. ${ }^{4}$

Uterine leiomyomas are benign uterine tumors of unknown etiology. These kinds of lesions seem to arise from myometrial transformation. The majority of these estrogen dependent uterine neoplasms afflict mostly women of reproductive age group and $80 \%$ of them suffer from this during their whole lifetime 5 . Uterine leiomyoma growth is strictly related to estrogens and their receptors. Estrogens may exert growth stimulatory effects on leiomyomas intermediated by cytokines, growth factors or apoptosis factors ${ }^{6}$. Progesterone interacts with its receptors PR-A and PR-B playing a key role in leiomyoma biologies. Progesterone can stimulate leiomyoma cell growth and survival through upregulating $\mathrm{Bcl}-2$ protein expression and downregulating TNF- $\alpha$ expression. ${ }^{7,8} \mathrm{High}$ estrogen level is associated with an increased risk of fibroid in midlife women (42-57 years) who never reported of fibroids before. Conversely the risk of recurrent fibroid was mitigated in women with high $\mathrm{E}_{2}{ }^{9}$

Adenomyosis is a distinct pathologic entity, not physiologic or neoplastic, characterized by heterotopic endometrium in hyperplastic endometrium. ${ }^{10}$ Adenomyosis isalso an estrogen dependent disease caused by a downward extension of the endometrium into the uterine myometrium. Endometrium from women without endometrial disorders were used as controls. In estrogen receptor positive cultured (Ishikawa) endometrial cells, estrogen induced a morphological change to fibroblast like phenotype, a shift from epithelial- mesenchymal transition ${ }^{11}$. Adenomyotic lesions produce significant quantities of progesterone and contain strikingly lower levels of $\mathrm{PR}^{12,13}$. The protective role of progesterone in endometrial cancer is not completely applicable in adenomyosis, since adenomyosis is not a pure epithelial proliferation but rather an increased inflammation and cell survival due to diminished apoptosis or differentiation $^{14,}{ }^{15}$. High estrogen concentration and impaired immune related growth control in ectopic endometrium may be necessary for maintenance of adenomyosis ${ }^{16}$.

Different literatures reviewed, had revealed unopposed hyperestrogenic state is the most common cause endometrial hyperplasia ${ }^{4}$. It is a well-known fact that hyperestrogenic state is one of the most important factors responsible for the growth of leiomyoma. Hyperestrogenic states are also associated with endometrial hyperplasia, which is a precursor lesion of endometrial adenocarcinoma, particularly when associated with nuclear atypia. Adenomyosis is also frequently associated with endometrial hyperplasia, possibly because of its association with hyperestrogenic states. But so far no literature has compared the endometrial findings in adenomyosis and leiomyoma.

Considering the postulate of hyperestrogenic state in both adenomyosis and leiomyoma, the endometrial changes may be seen in both condition and therefore can be assessed on that basis, to find out the possible causative association between adenomyosis, leiomyoma and endometrial hyperplasia or any other specific changes in endometrium.

Similarly, it has also been found that progesterone receptors are increased in leiomyomas whereas decreased PR in the ectopic endometrium has been found in adenomyosis.

So, the levels of these two hormones that is estrogen and progesterone can be estimated in the serum of the respective patients to assess their 
correlation in the pathogenesis of both these conditions.

As estradiol is the most potent estrogen present during the reproductive age group. Hence, here the level of estradiol is measured.

\section{Materials and Methods}

The study was conducted over a period of 12 months from June 2016 to July 2017.

Hysterectomy specimens of patients diagnosed with leiomyoma and adenomyosis with or without salphingo- oophorectomy were sent from the Operation Theatre of Gynecology and Obstetrics Department to the Pathology Department along with duly filled up consent and case record form. Study group comprised of 73 cases of adenomyosis and 73 cases of leiomyoma. The blood of the patients were collected and send to the Department of Biochemistry for estradiol and progesterone measurement.

After gross examination, sections from the Endomyometrium at $1 \mathrm{~cm}$ interval were taken and processed. Haematoxylin and eosin staining were done on the slides that were prepared from the sections.

\section{Results}

In leiomyoma $63.01 \%$ of patients and in adenomyosis $53.42 \%$ belonged to the age group of 41-45 years. The most common presenting complain in both the pathologies was menorrhagia (57.53\% in leiomyoma, $75.34 \%$ in adenomyosis). In both cases, majority of the patients had their menarche in the age group of $12-14$ years $(87.67 \%$ in leiomyoma, $73.97 \%$ in adenomyosis).

Table 1: Endometrial histopathological findings in leiomyoma

\begin{tabular}{|l|c|c|}
\hline Histopathology & $\begin{array}{c}\text { No of } \\
\text { patients }\end{array}$ & $\%$ \\
\hline Inactive basal Endometrium & 36 & 49.31 \\
\hline Simple endometrial hyperplasia & 1 & 1.36 \\
\hline Secretory endometrium & 15 & 20.54 \\
\hline Proliferative endometrium & 21 & 28.76 \\
\hline Total & 73 & 100 \\
\hline
\end{tabular}

Table 2: Endometrial histopathological findings in adenomyosis

\begin{tabular}{|l|c|c|}
\hline Histopathology endometrial & No of patients & $\%$ \\
\hline $\begin{array}{l}\text { Simple } \\
\text { hyperplasia }\end{array}$ & 30 & 41.09 \\
\hline Secretory endometrium & 14 & 19.17 \\
\hline Proliferative endometrium & 25 & 34.24 \\
\hline $\begin{array}{l}\text { Endometrial hyperplasia } \\
\text { with atypia }\end{array}$ & 2 & 2.73 \\
\hline Endometrial carcinoma & 2 & 2.73 \\
\hline Total & 73 & 100 \\
\hline
\end{tabular}

Table 3: Associated endometrial pathologies in leiomyoma and adenomyosis

\begin{tabular}{|l|c|c|c|}
\hline $\begin{array}{l}\text { Associated } \\
\text { pathologies }\end{array}$ & $\begin{array}{c}\text { Adenomyo } \\
\text { sis\& \% of } \\
\text { total }\end{array}$ & $\begin{array}{c}\text { Leiomyom } \\
\text { a\& \% of } \\
\text { total }\end{array}$ & Total\& \% \\
\hline $\begin{array}{l}\text { Simple } \\
\text { endometrial } \\
\text { hyperplasia }\end{array}$ & $\begin{array}{c}30 \\
(96.77 \%)\end{array}$ & $1(3.22 \%)$ & $31(100 \%)$ \\
\hline $\begin{array}{l}\text { Endometrial } \\
\text { hyperplasia with } \\
\text { atypia }\end{array}$ & $2(100 \%)$ & $0(0 \%)$ & $2(100 \%)$ \\
\hline $\begin{array}{l}\text { Endometrial } \\
\text { carcinoma }\end{array}$ & $2(100 \%)$ & $0(0 \%)$ & $2(100 \%)$ \\
\hline $\begin{array}{l}\text { Inactive basal } \\
\text { endometrium }\end{array}$ & $0(0 \%)$ & $36(100 \%)$ & $36(100 \%)$ \\
\hline
\end{tabular}

Thus we see that maximum number of pathologies like endometrial hyperplasia with atypia, endometrial carcinoma and simple endometrial hyperplasia are associated with adenomyosis. While only inactive basal endometrium is found in leiomyoma.

Each patient's estradiol level was assessed on the basis of the following range-

Follicular phase- 15 to $112 \mathrm{pg} / \mathrm{ml}$

Preovulatory phase- 136 to $251 \mathrm{pg} / \mathrm{ml}$

Luteal phase- 48 to $172 \mathrm{pg} / \mathrm{ml}$

Each patient's progesterone was assessed on the basis of the following range-

Follicular phase- 0.4 to $2.3 \mathrm{ng} / \mathrm{ml}$

Luteal phase- 1.2 to $18.8 \mathrm{ng} / \mathrm{ml}$ 
Table 4: Estradiol and progesterone levels in adenomyosis

\begin{tabular}{|l|c|c|c|}
\hline Estradiol & $\begin{array}{c}\text { No of patients } \\
\& \%\end{array}$ & Progesterone & $\begin{array}{c}\text { No of } \\
\text { patients \& } \%\end{array}$ \\
\hline Low & $9(12.32 \%)$ & Low & $9(12.32 \%)$ \\
\hline Normal & $42(57.53 \%)$ & Normal & $59(80.82 \%)$ \\
\hline High & $22(30.13 \%)$ & High & $5(6.84 \%)$ \\
\hline Total & $73(100 \%)$ & Total & $73(100 \%)$ \\
\hline
\end{tabular}

Table 5: Estradiol and progesterone levels in leiomyoma

\begin{tabular}{|l|c|c|c|}
\hline Estradiol & $\begin{array}{c}\text { No of patients } \\
\& \%\end{array}$ & Progesterone & $\begin{array}{c}\text { No of patients } \\
\& \%\end{array}$ \\
\hline Low & $23(31.50 \%)$ & Low & $14(19.17 \%)$ \\
\hline Normal & $39(53.42 \%)$ & Normal & $52(71.23 \%)$ \\
\hline High & $11(15.06 \%)$ & High & $7(9.58 \%)$ \\
\hline Total & $73(100 \%)$ & Total & $73(100 \%)$ \\
\hline
\end{tabular}

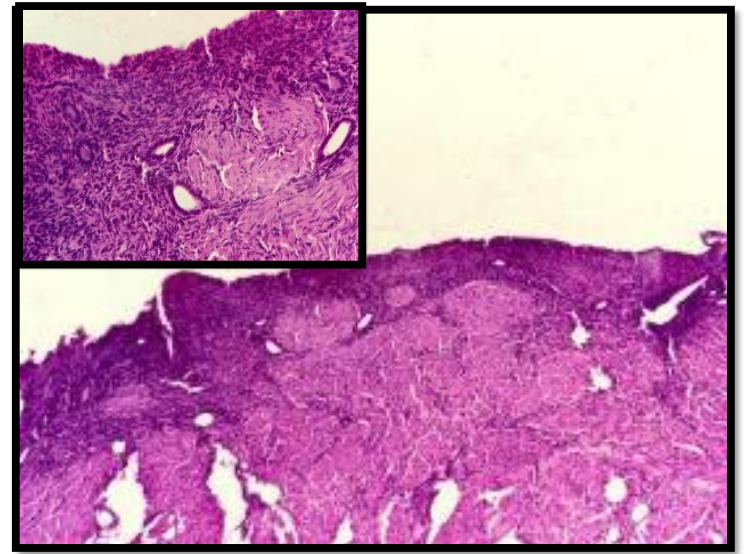

Figure 1: Inactive basal endometrium (H\&E, 100x); inset at 400x.

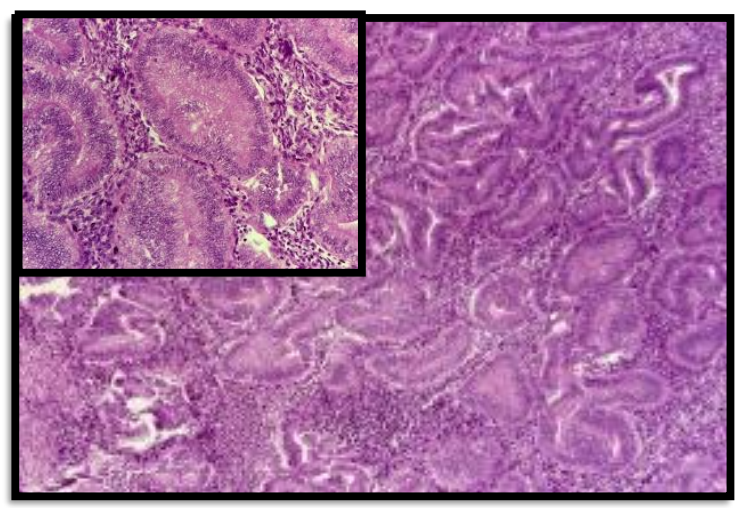

Figure 2: Simple endometrial hyperplasia $(H \& E$, $100 x$ ); inset at 400x.

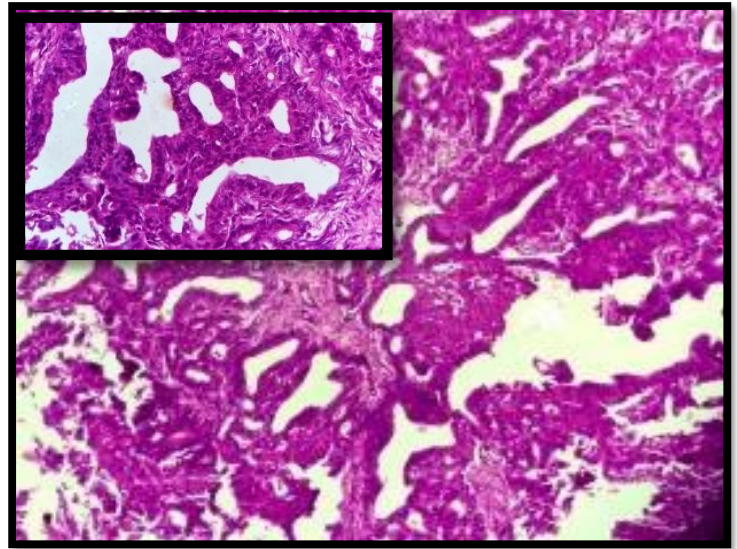

Figure 3: Complex atypical endometrial hyperplasia (H\&E, 100x); inset at 400x.

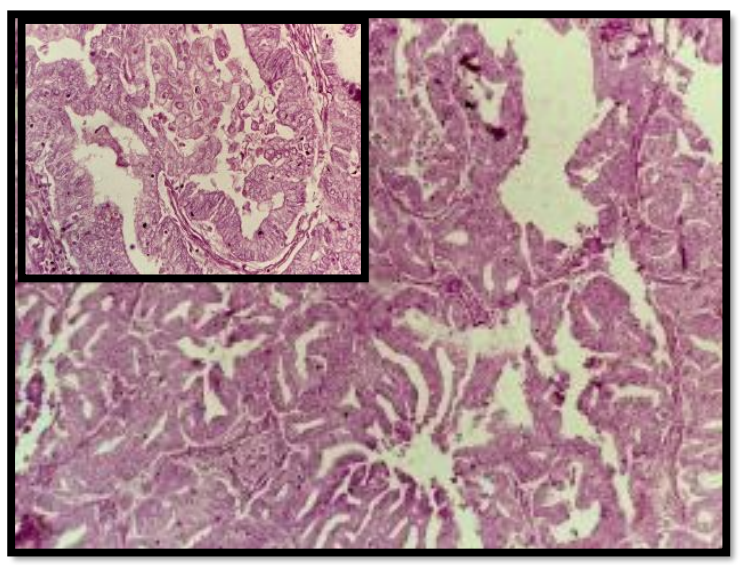

Figure 4: Endometrial adenocarcinoma (H\&E, $100 x$ ); inset at 400x.

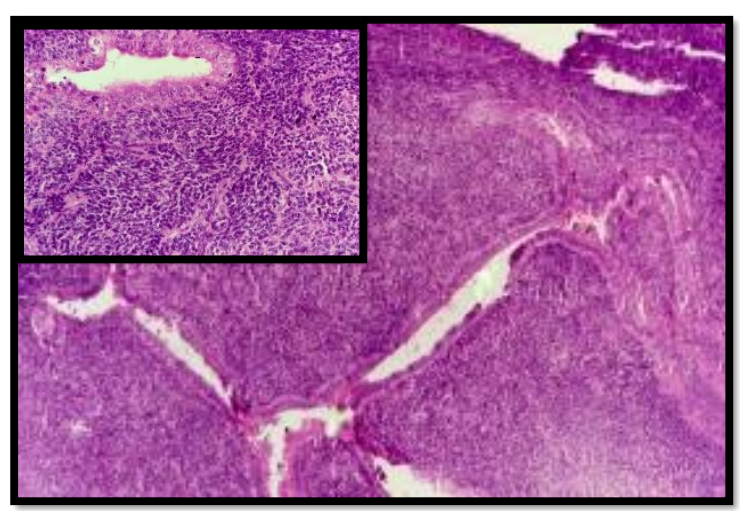

Figure 5: Adenomyosis (H\&E, 100x); inset at 400x 


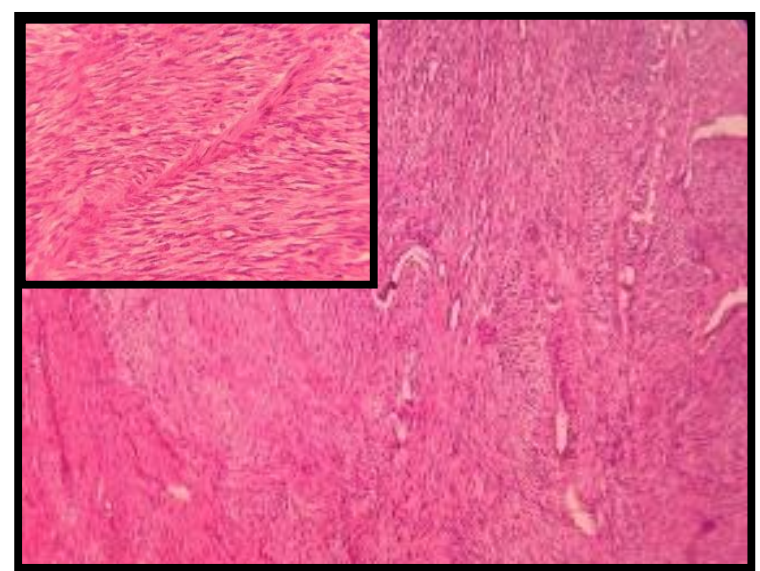

Figure 6: Leiomyoma (H\&E, 100x); inset at 400x

\section{Discussion}

In the study conducted by Deligdish, Lowenthal $M^{17}$ in the year 1970, they found that the endometrial changes found in leiomyomas were distortion, dilatation and atrophy of the endometrial glands lying in close proximity of myomas. They thought hormonal factors and mechanical factors were responsible. Similarly, Mannem, Kumar H, Munikrishna $\mathrm{M}^{18}$ concluded that leiomyoma is a steroid dependant tumor where a mixed finding of proliferative phase, hyperplasia, and endometrial atrophy can be found. This corroborated with the study, as we found a wide variety of endometrial changes ranging from secretory endometrium, proliferative endometrium, and endometrial hyperplasia to inactive basal endometrium (atrophic).

Ferenczy $A^{16}$ in the year 1998 postulated that adenomyosis was triggered by relatively high estrogen concentration and impaired immune related growth control. Hence, smooth muscle hypertrophy and hyperplasia along with endometrial proliferation are quite common in adenomyosis hyperplasia. In our study simple endometrial hyperplasia was the most common finding as expected.

Ferenczy $\mathrm{A}^{16}$ has also stated that adenomyosis is mostly associated with other endometrial pathologies like endometrial polyps (2.3\%), endometrial hyperplasia (7\%), atypical endometrial hyperplasia (3.5\%), adenocarcinoma (1.4\%). Whereas, Deligdish, Lowenthal $\mathrm{M}^{17}$ had stated that leiomyoma is associated with the pathology of endometrial atrophy most commonly. We found endometrial hyperplasia, atypical endometrial hyperplasia, and endometrial adenocarcinoma in the endometrium of patients with adenomyosis and leiomyoma patients had atrophic endometrium

The study conducted by Chen, Wang, Yen ${ }^{18}$ et al in the year 2014 showed that 30 adenomyosis patients and 30 controls did not have much difference in the serum levels of estradiol and progesterone as we found in our study.

In another study conducted by Englund, Blanck, Gustavson ${ }^{19}$ in the year 1998 the concentration of serum estradiol and progesterone level in 14 leiomyoma patients $(55.55 \%)$ were within normal range thus echoing our findings as well.

\section{Conclusion}

To conclude, we can say that on comparison of endometrial changes in adenomyosis and leiomyoma, we found that in spite of having hyperestrogenic state as a factor for growth, leiomyoma shows inactive basal endometrium. Adenomyosis is most frequently associated with other endometrial pathologies.

We also concluded that the serum level of estradiol and progesterone in most cases were normal. Hence, the hyperestrogenic state is probably a localized phenomenon within the uterus.

\section{References}

1. Deligdisch L. Hormonal pathology of endometrium. Modern Pathology, 2000; 13(3): 285-294.

2. Damle RP, Dravid NV. Clinicopathological spectrum of endometrial changes in Perimenopausal \&Post menopausal Abnormal uterine bleeding- A 2 years study. J Clinical Diagnostic Res, 2013 December; 7(12):2774-2776.

3. Kumar, Abbas, Aster. Robbins and Cotran Pathologic basis of disease. $9^{\text {th }}$ edition. South Asia Edition: Elsevier, 2015. Vol 2. 
Chapter 22. The Female Genital Tract;p.1012-1021.

4. Montgomery Ben E, Daum GS, Dunton CJ. Endometrial hyperplasia- A Review. Obstetrical and Gynecological Survey, 2004 May; 59(5): 368-378.

5. Ciavattini A, Giuseppe JD, Stortoni P, Montik N, Giannubilo SR, Litta P, Islam Md S, Tranquilli AL, Reis FM, Ciarmela P. Uterine Fibroids: Pathogenesis and Interactions with Endometrium and Endomyometrial Junction. Obstetrics and Gynecology International, 2013.dx.doi.org/10.1155/2013/173184.

6. Grings AO, Lora V, Ferreira GD, Brum IS, Corleta HVE, Capp E. " Protein expression of estrogen receptors $\alpha$ and $\beta$ and aromatase in myometrium and uterine leiomyoma". Gynecologic and Obstetrics Investigation, 2012; 73(2): 113- 117.

7. Kurachi O, Matsuo H, Samoto T, Maruo T. - Tumor necrosis factor $\alpha$-expression in human uterine leiomyoma and its downregulation by progesteronell. Journal of Clinical Endocrinology and Metabolism, 2001; 86(5):2275-2280.

8. Yin $\mathrm{P}$, Lin Z, Cheng YH, Marsh EE, Utsunomiya $\mathrm{H}$, Ishikawa $\mathrm{H}$, Xue Q, Reierstad S, Innes J, Thung S, Kim JJ, Xu E, Bulun SE. Progesterone receptor regulates $\mathrm{Bcl}-2$ gene expression through direct binding to its promoter region in uterine leiomyoma cells. J Clin Endocrinology and Metabolism, 2007 Nov; 92(11): 4459-66.

9. Wong JY, Gold EB, Johnson WO, Lee JSCirculating sex hormones and risk of uterine fibroids- Study of Women's Health Across the Nation (SWAN); The Journal Of Endocrinology \& Metabolism, 2016 January; 101 (1):123-30.

10. Hunter WC, Smith LL, Reiner WC. Uterine adenomyosis- Incidence, symptoms and pathology in 1,856 hysterectomies. American Journal of Obstetrics and Gynecology, 1947.dx.doi.org/10.1016/00029378(47)90286-X.

11. Chen YJ, Li HY, Huang CH, Twu NF, Yen MS, Wang PH, Chou TY, Liu YN, Chao KC and Yang $\mathrm{MH}-$ Oestrogen-induced epithelial-mesenchymal transition of endometrial epithelial cells contributes to the development of adenomyosis, The Journal Of Pathology, 2010 Nov; 222(3):261-270.

12. Chwalisz K, Perez MC, DeManno D, Winkel C, Schubert G, Elger W. Selective progesterone receptor modulator development and use in the treatment of leiomyomata and endometriosis. Endocrine Reviews, 2005 May; 26(3):423-438.

13. Kim JJ, Kurita T, Bulun SE. Progesterone action in endometrial cancer, endometriosis, uterine fibroids and breast cancer. Endocrine Reviews, 2013; Vol34: 130-162.

14. Lee WL, Lee FK, Su WH, Tsui KH, Kuo CD, Hsieh SL, Wang PH. Hormone therapy for younger patients with endometrial cancer. Taiwanese Journal of Obstetrics and Gynecology. 2012; 51(4):495-505.

15. Cheng MH, Chen JF, Fuh JL, Lee WL, Wang PH. Osteoporosis treatment in postmenopausal women with pre- existing fracture. Taiwanese Journal of Obstetrics and Gynecology. 2012; 51(2):153-166.

16. Ferenczy A- Pathophysiology of Adenomyosis. Human Reproduction Update, 1998; (4): 312-322.

17. Deligdish L, Loewenthal M.-Endometrial changes associated with myomata of uterus J Clinical Pathology, 1970 ; 23(8);676-80.

18. Chethana M, Harendra Kumar $\mathrm{ML}^{1}$, Munikrishna $\mathrm{M}^{2}$, Department of Pathology, Kempegowda Institute of Medical Sciences, Bengaluru, Department of Pathology and Obstetrics and Gynaecology ${ }^{2}$, Sri Devaraj Urs Medical College, Tamaka, KolarEndometrial changes in Uterine Leiomyomas J Clinical Biomedical Science, $2013 ; 3(2) ; 72-79$. 
19. Chen YZ, Wang JH, Yan J, Liang Y, Zhang XF, Zhou F- Increased expression of adult stem cell marker Musashi-1in the ectopic endometrium of adenomyosis does not correlate with serum estradiol and progesterone levels; European Journal of Obstetrics \& Gynecology \&Reproductive Biology 173 (2014), pp 88- 93.

20. Englund K, Blanck A, Gustavson I, Lundkvist U, Sjoblom P, Norgren A, Lindblom B- Sex steroid hormones in Human myometrium and Fibroids- changes during menstrual cycle and gonadotrophin releasing hormone treatment; The Journal of Clinical Endocrinology and Metabolism; 1998; Volume 83; pp4092-6. 